\title{
Contribution to the pathology of spontaneous adiaspiromycosis in small mammals
}

\author{
par K. BLAŽEK et J. PROKOPIČ \\ Institute of Parasitology, Czechoslovak Academy of Sciences, Prague
}

\section{Summary.}

A description is given of the pathological reaction of the lung tissue of small rodents and insectivores to spontaneous infection with the fungus Emmonsia crescens. No differences were observed in the reaction of the tissue of either the individual hosts or within the various seasons. These facts suggest that the origin of a granulomatous reaction to the presence of the adiaspore in small mammals may be a process associated with an early or still florid infection. In three cases, the authors observed verrucose proliferations on the outer layer of the adiaspore wall, and minute spherical bodies situated close to the mother adiaspore. In their opinion the phenomenon under consideration is the formation of daughter adiaspores (spherules). This finding is important because it may help in explaining of several lung changes.

In $A$. flavicollis and A. sylvaticus from Bulgaria, the authors found granulomatous pneumonia and minute adiaspores which they believe to be adiaspores of the species Emmonsia parva.

\section{Résumé.}

Contribution à l'étude de la pathologie de l'adiaspiromycose des petits Mammifères.

Les réactions pathologiques du tissu pulmonaire de petits Rongeurs et d'Insectivores sont décrites. Aucune différence n'a été notée selon les individus, ni selon les saisons. Les A.A. en déduisent que les réactions granulomateuses à la présence des adiaspores sont peut-être un processus lié à une infection précoce et persistante. Dans 3 cas, ils ont observé Annales de Parasitologie humaine et comparée (Paris), t. 49, $\mathrm{n}^{\circ} 2$ 
des proliférations verruqueuses sur la tunique externe de la paroi de l'adiaspore et de minces corpuscules sphériques au voisinage de l'adiaspore mère. Ces «sphérules » sont interprétées comme des adiaspores filles. Cette observation est importante, car elle pourrait contribuer à expliquer certaines modifications histologiques du poumon.

Chez $A$. flavicollis et $A$. sylvaticus, les A.A. ont observé une pneumonie granulomateuse ainsi que de minces adiaspores qu'ils présument appartenir à l'espèce Emmonsia parva.

The reaction of the lung tissue to adiaspores of the genus Emmonsia is not uniform. Sometimes, the lung tissue is pressed apart by the adiaspores; the general pathological reaction is insignifiant apart from the collapse of the closeby alveoli, and a moderate desquamation of the alveolar epithelium. In some instances, histiocytic granulomas with a connective tissue encapsulation are formed around the adiaspores, in other instances, a marked exudation of neutrophilic granulocytes originates around the adiaspores (Sharapov 1969 ; Slais et al. 1970 ; Doory et al. 1971). Sharapov (1969) observed even necrosis. Although no explanation is available as yet of these differences in tissue reaction, it appears the degree of reaction may depend on the age of the infection (Dvořák 1966, Sharapov 1969).

During our field investigation of adiaspiromycosis in small mammals, we examined the lungs with histological methods in order to assess whether a certain form of tissue reaction is typical of a certain host species, and to obtain information on possible peculiarities of the pathological picture of spontaneous adiaspiromycosis and on the morphology of the fungus because knowledge of the pathogenesis of this infection is scarce.

\section{Material and Methods.}

The material for histological examination was obtained from 69 small mammals (7 rodent species and 4 insectivore species). The species represented in this material were these: Sorex araneus (6), Erinaceus europaeus and roumanicus (4), Talpa europaea (4), Crocidura leucodon (1), Ondatra zibethica (2), Apodemus sylvaticus (7), Microtus agrestis (5), Clethrionomys glareolus (15), A. flavicollis (8), M. arvalis (16), Neomys fodiens (1). Sixty two positive lung samples were obtained from animals trapped in two localities of Czechoslovakia, and 7 positive samples from animals trapped in Bulgaria during our field expedition. Since the distribution of adiaspores was generally uniform in both lungs, we examined one lung of each animal only by the compression method, and, if this was found to be positive, kept the other lung for histological examination. The lungs were fixed with $10 \%$ formalin or, exceptionally, $70 \%$ alcohol and embedded in paraffin with standard techniques. Sections were stained with hemalum - eosin, van Giesons' method and Massons' trichrome ; in addition, we tested Mc Manus' PAS reaction, Grocott's and Kossa's reactions. If adiaspores were not found in the number of sections customary for diagnostic purposes, we made semiseries of sections. 


\section{Results.}

Our evaluation of lung tissue reaction disclosed that a granulomatous reaction occured in approximately $50 \%$ of $M$. arvalis and $A$. sylvaticus examined; this reaction was less frequent in the remaining species. We found, however, in the same host, adiaspores without a distinct reaction of the adjacent tissue together with a cellular reaction of varying degree. Frequently, large adiaspores measuring approximately from 200-300 $\mu \mathrm{m}$ in diameter, were found to compress the surrounding alveoli (fig. 6) and, in the most distant alveoli, alveolar macrophages were present. On several occasions we observed a narrow strip of fibrous tissue around the adiaspore, evidently due to the collapse of the alveoli. In other instances, the presence of alveolar macrophages was accompanied by the presence of histiocytes, lymphocytes and an occasional multinucleate cell without, however, a more marked granuloma formation (fig. 3). Granulomas were formed mainly around adiaspores measuring 100-130 $\mathrm{um}$ at the utmost, while the diameter of the section through the granuloma was $200 \mu \mathrm{m}$ or slightly more. Less frequently, granulation tissue originated around an adiaspore measuring from 260-300 $\mu \mathrm{m}$. Granulomas originated around adiaspores located in the alveoli or alveolar ducts, frequently close to the bronchi (fig. 2). Several granulomas harboured two adiaspores (fig. 1, 3).

Granulation tissue was formed by histiocytes (figs. 1, 2) with an admixture of lymphocytes and plasma cells. Sometimes, the latter dominated, or formed a zone along the border surrounding the histiocytic granuloma with the adiaspore (fig. 2). Often, the granulation tissue contained mitotic formations. Giant multinucleate cells of the foreign body type abutted the outer surface of the adiaspore, or were dispersed in the granulation tissue among uninucleate spherical elements. The initial stage of fibroblast proliferation was clearly visible on the periphery of the granuloma. In cases of massive infection, desquamative alveolitis, peribronchial lymphocytic infiltration and hyperplasia of the peribronchial and perivascular lymphoid tissue were formed at some distance from the adiaspores. In one case (Sorex araneus) the granulation tissue around the adiaspore had succumbed to necrosis.

The adiaspores found in the lungs of the animals examined measured generally from 100-300 $\mu \mathrm{m}$ in diameter, and their structure was typical. A three- to fourlayered membrane with a smooth surface (36-48 $\mu \mathrm{m}$ thick) enclosed a granulated, basophilic substance of honeycomb-like structure (fig. 6) or unstained spherical bodies (fig. 4, $9 \mathrm{~B}$ ). In three animals (twice in Microtus arvalis, in May; once in Clethrionomys glareolus, in December), we found large adiaspores measuring approximately $200-250 \mu \mathrm{m}$ in diameter, surrounded by a weak histiocytic reaction. On the outer layer of the adiasporic membrane, we observed numerous verrucose proliferations of semispherical shape which either abutted the superficial membrane of the mother adiaspore or were connected with it by wide stalks (fig. 7, 8, 9). Sometimes, the stalks were constricted, or spherical bodies were situated near the adiaspore (fig. $7 \mathrm{~B}, 10$ ). These formations measured from $6-14 \mu \mathrm{m}$ in diameter; from some of them arose a new «bud » similar to a short «hypha (fig. $8 \mathrm{~A}$ ). Several of these pedunculate processes terminated, in a cup-like formation (fig. $7 \mathrm{~A}$ ). The spherical 
bodies close to the adiaspore were mostly double-contoured and attained a size of 28-30 $\mu \mathrm{m}$ (fig. 10). With Mc Manus method most of the globules stained a vivid pink or red, or remained almost unstained. With Masson's trichrome their membrane stained orange, the content blue, with Grocott, the content stained black.

A remarkable feature in our material was the finding of very small adiaspores in two rodents, i.e. in $A$. flavicollis and $A$. sylvaticus (fig. 3, 4) both from the mouth of the Batovo River in Bulgaria. In both cases, the adiaspores were uniform, their size ranged from $18-48 \mu \mathrm{m}$ in $A$. flavicollis, from $38-60 \mu \mathrm{m}$ in A. sylvaticus. The measurements of most adiaspores remained at lower limits, an occasional adiaspore only attained top limits. In both cases infection was accompanied by granulomatous pneumonia.

\section{Discussion.}

In spite of the fact that a granulomatous reaction around the adiaspores was found to occur more frequently with $M$. arvalis and $A$. sylvaticus than with the remaining species examined it is difficult to infer that this type of reaction is typical of the two animal species particularly in view of the fact that our material was limited and, hence, unsuitable for statistical evaluation. As regards the concomitant incidence of adiaspores with a granulomatous reaction and those without a reaction in the same animal, and, also, that granulomas were found mainly around adiaspores of a smaller size than that given for a fully grown adiaspore, we assume that a granulomatous inflammation accompanies an early and still florid infection, whereby a certain role may be played also by the enzymatic activity of the growing adiaspore.

A dependance of the type of tissue reaction on the seasons has not been observed. The type of tissue reaction in the lungs disclosed in our material is consistent with that described by other authors (Bakerspigel 1968, Sharapov 1969). A massive incedence of large adiaspores in the lungs is, undoubtedly, responsible for the dysfunction of the lungs even without the presence of a marked pathological reaction of the lung tissue. Clinical symptoms of infection, however, become apparent only after the origin of granulomatous pneumonia which may be fatal in view of the diffuse affection of the liver tissue.

An interesting finding was that of budding adiaspores in the lungs, and of spherical bodies (daughter bodies) lying free in the granulation tissue close to the mother adiaspore or even in the bronchus. No information, however, is available on the origin of these daughter spherules during spontaneous adiaspiromycosis (Dvoŕák and Otčenášek 1965, Dvořák 1966, Sharapov 1969). By contrast, in the laboratory, budding was observed in adiaspores at $37^{\circ} \mathrm{C}$ after an exposure to room temperature for several hours (Sharapov 1969). By mimicking conditions under which budding occured in Emmonsia crescens grown in vitro, Sharapov (1969) found a budding adiaspore in the lungs of a suslik (Citellus erythrogenes) with experimental infection. After killing the infected animal the author kept the lungs for 7 hours at room temperature and then placed them into the incubator at $37{ }^{\circ} \mathrm{C}$. The adiaspore measured $109.8 \mu \mathrm{m}$ in diameter and spherical bodies of $30 \mu \mathrm{m}$ in diameter were found 


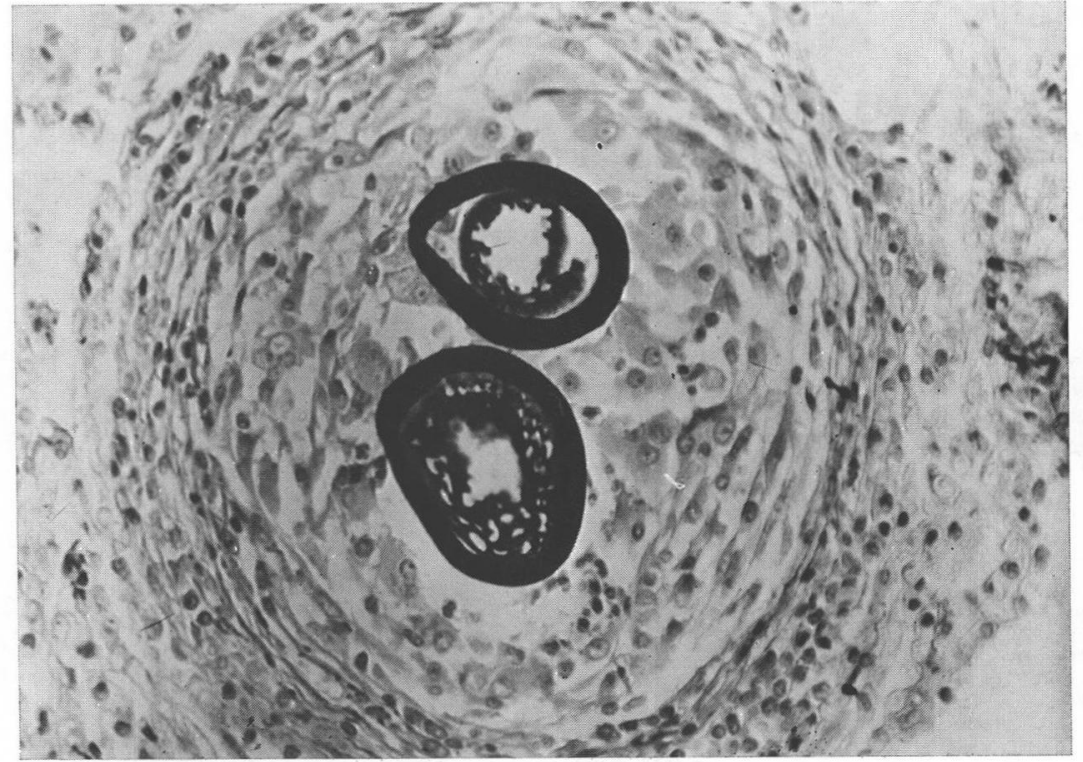

FIG. 1. - Two adiaspores of Emmonsia crescens from $M$. arvalis surrounded by a histiocytic granuloma. Grocott $(\times 250)$

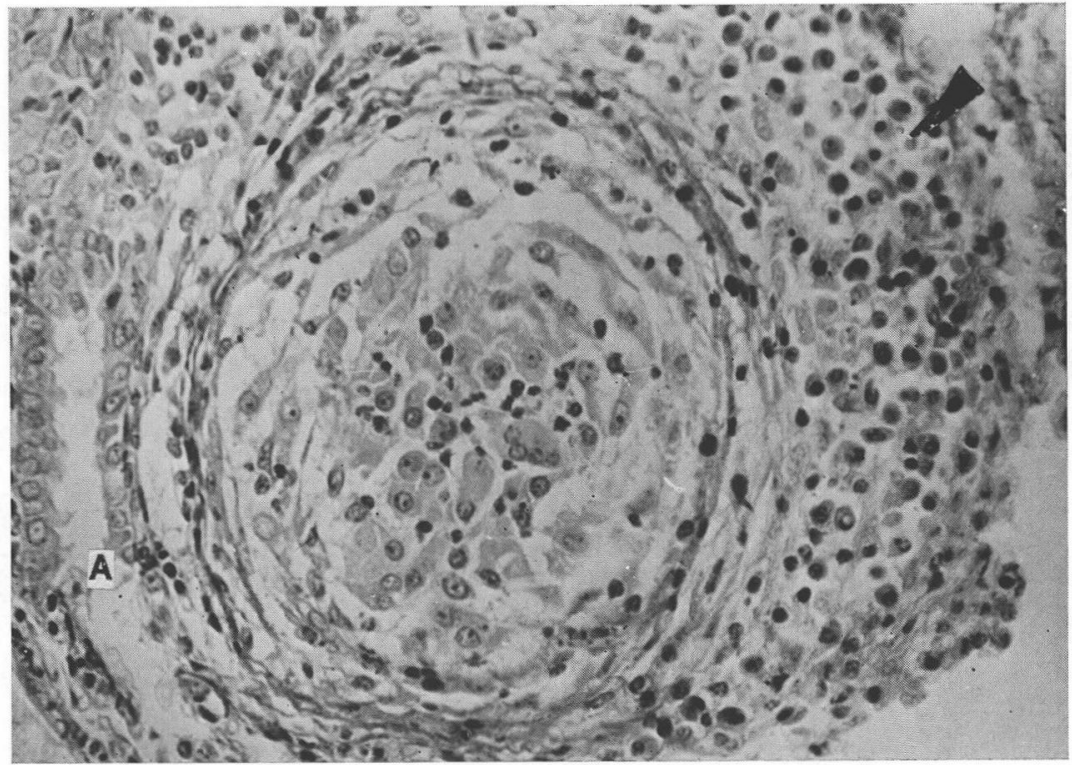

FIG. 2. - The marginal portion of a granuloma around an adiaspore which has not been encountered in the section. The periphery of the granuloma shows a wide zone of plasma cells and lymphoid cells. The granuloma lies near the bronchus (A). M. arvalis, Grocott $(\times 250)$ 


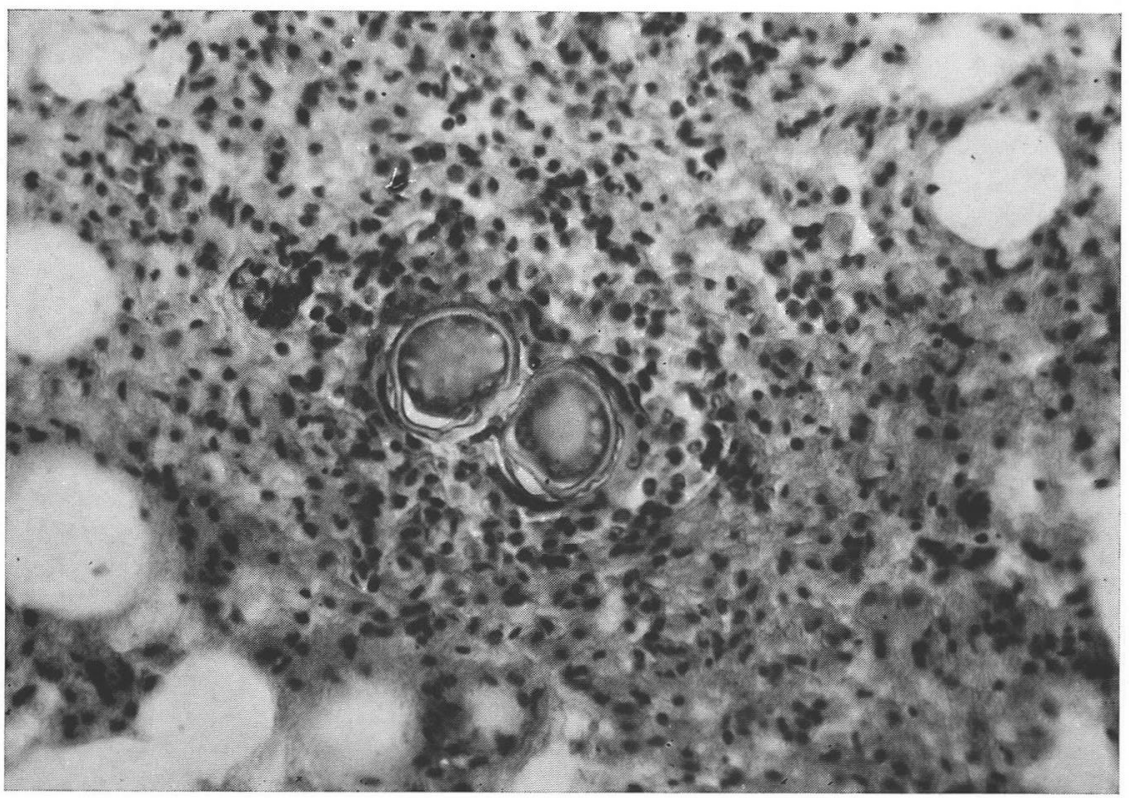

Fig. 3. - Two small adiaspores from the lungs of $A$. flavicollis, surrounded by lymphoid cells. E. parva suspected. HE (× 250)

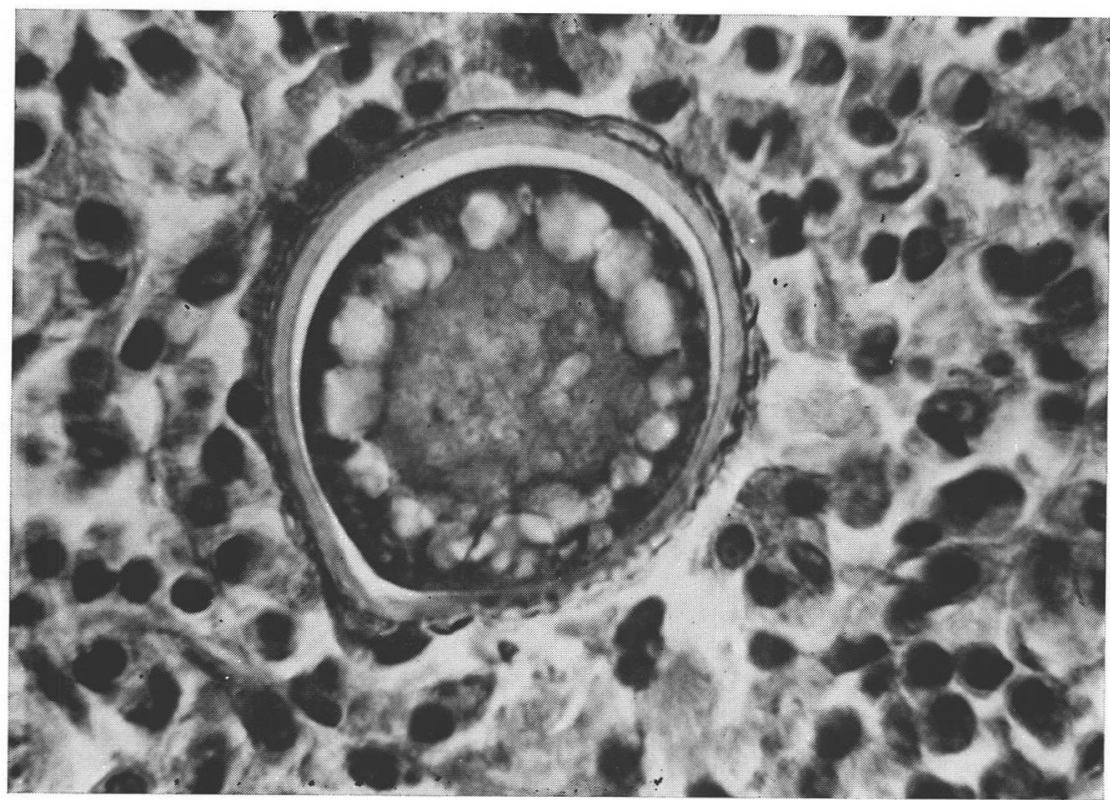

Fig. 4. - Detailed view on a small adiaspore surrounded with granuloma cells. HE $(\times 1000)$ 


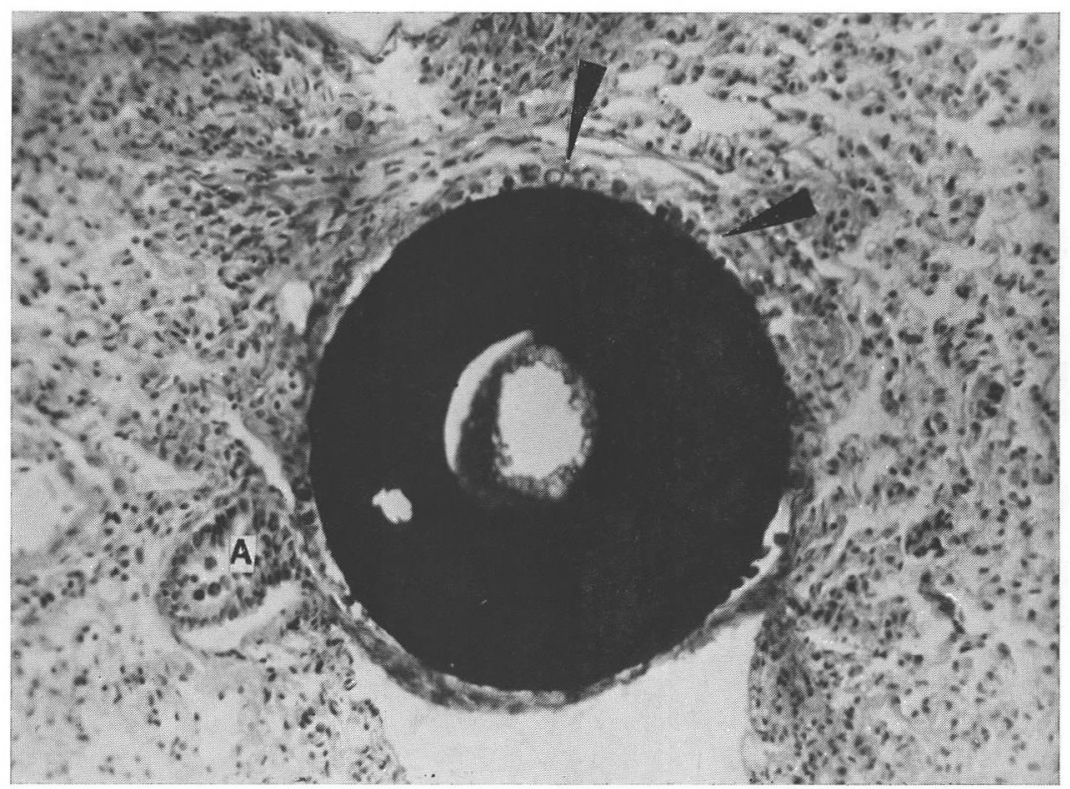

FIG. 5. - Adiaspore of E. crescens lying close to the bronchus (A.). The superficial layer of the adiaspore wall shows numerous verrucose proliferations (arrow). M. agrestis, McManus (X 130)

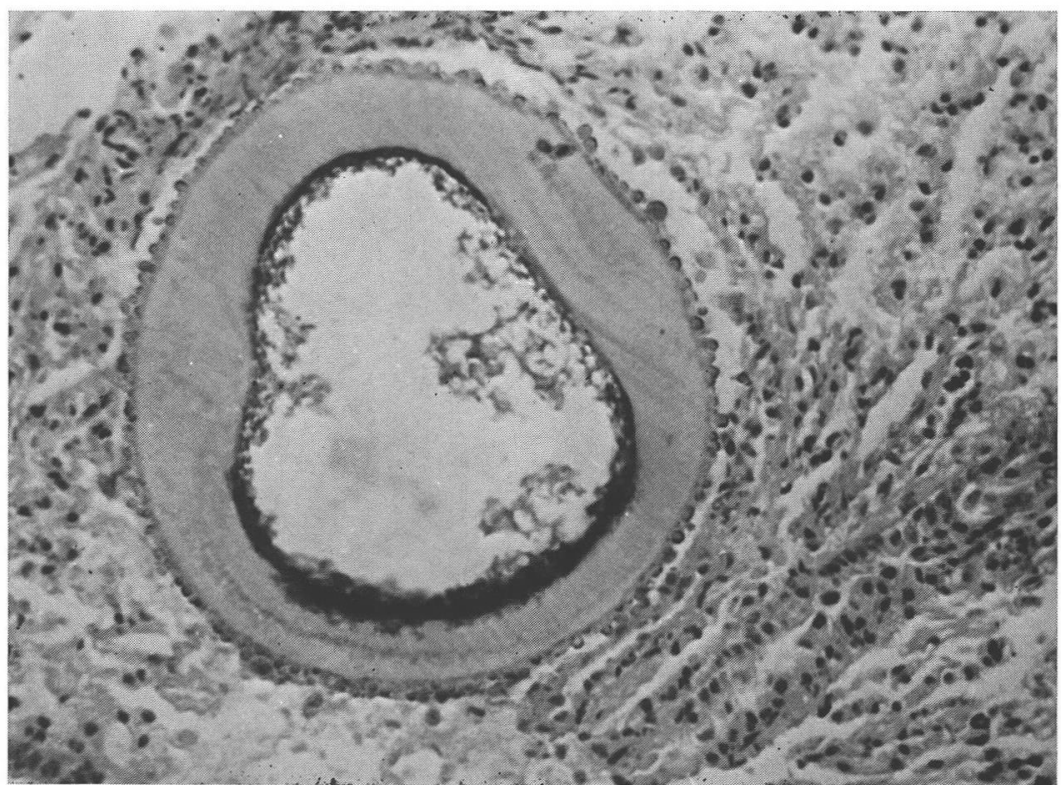

Fig. 6. - Adiaspore of E. crescens with verrucose formations on the surface. Close-by, collapsed lung alveoli and a weak cellulisation 


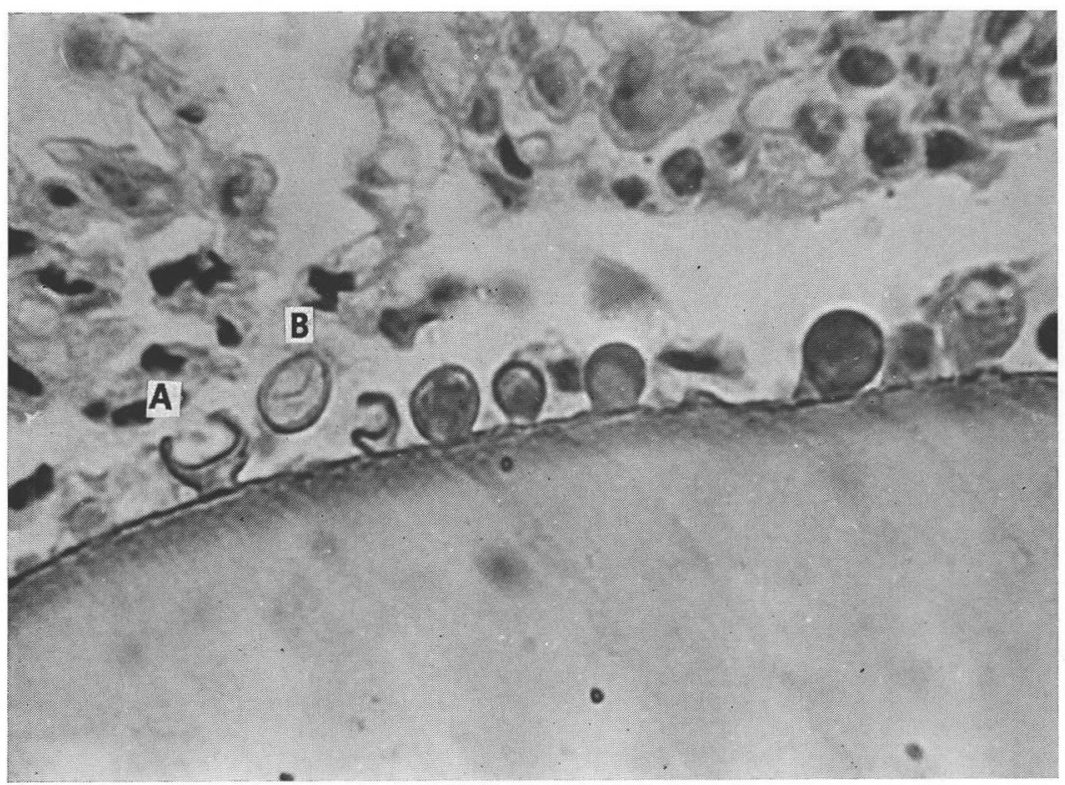

FIG. 7. - Detailed view on the proliferation of the outer membrane layer. Semispherical, pedunculate, cup-shaped formations (A). Free daughter globules (B). HE ( $\times 500)$

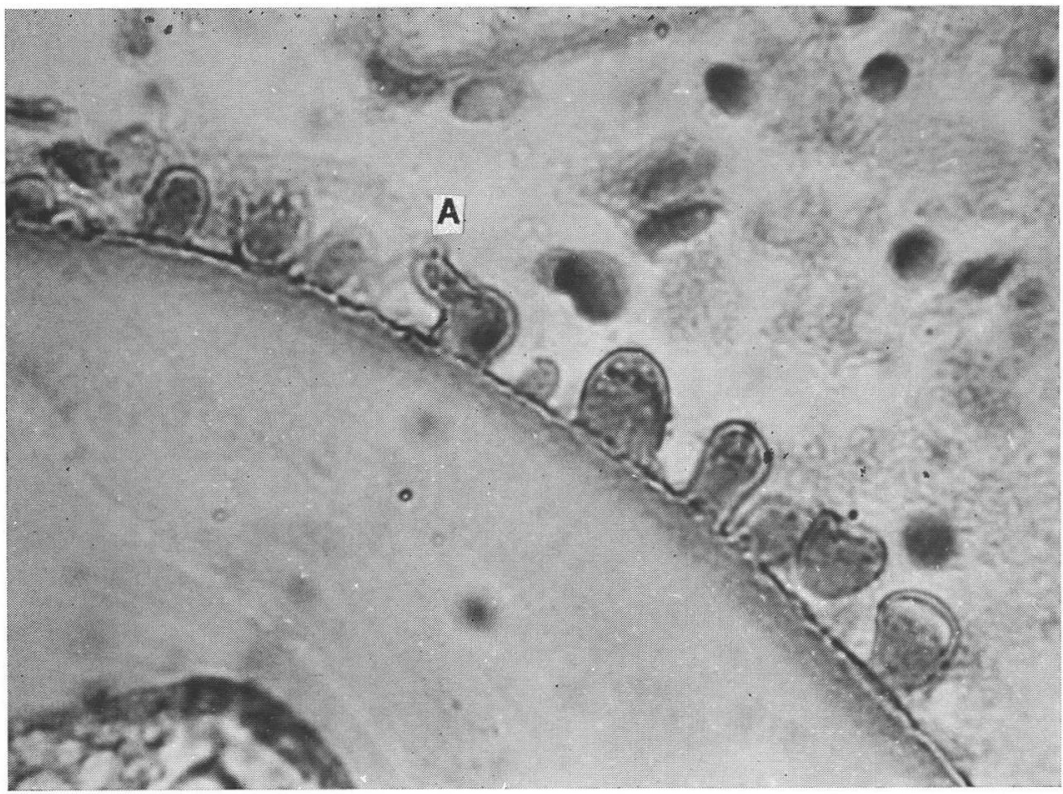

FIG. 8. - Another area of Fig. 7. A hypha-like formation (A) 


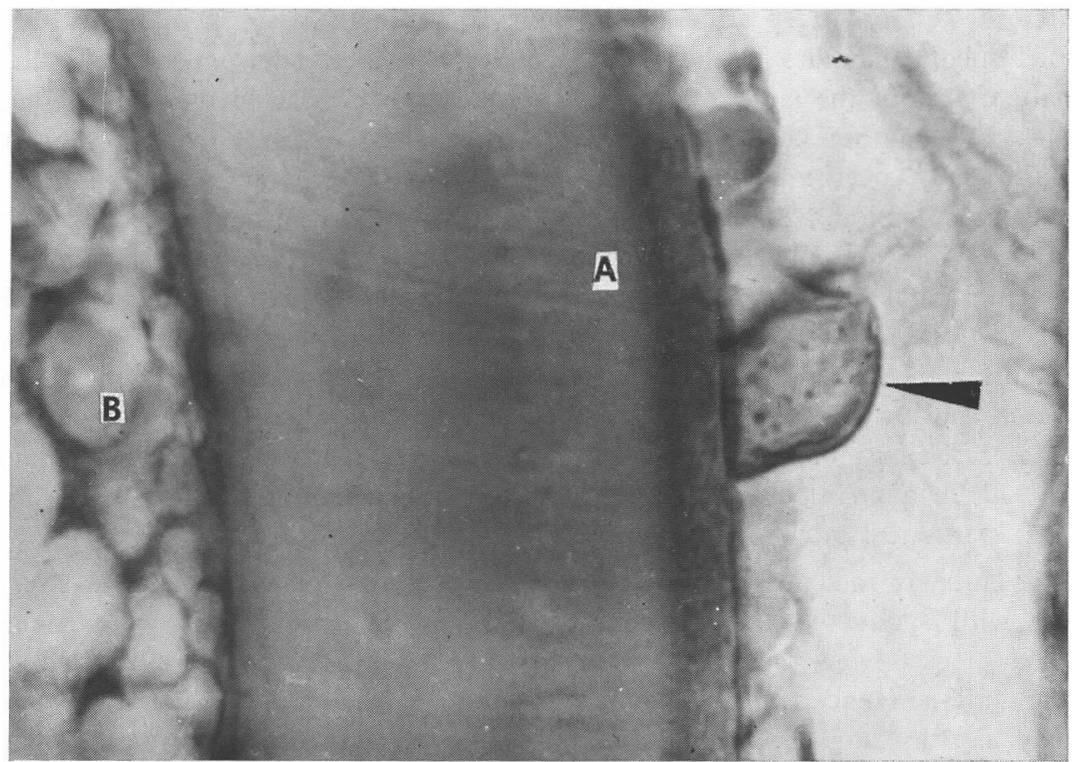

FIG. 9. - Detailed view on the extension (arrow) of the outer layer of the wall (A) of an $E$. crescens adiaspore. A distinct spherule (B) inside the adiaspore. $M$. agrestis; Masson's trichrome $(\times 1000)$

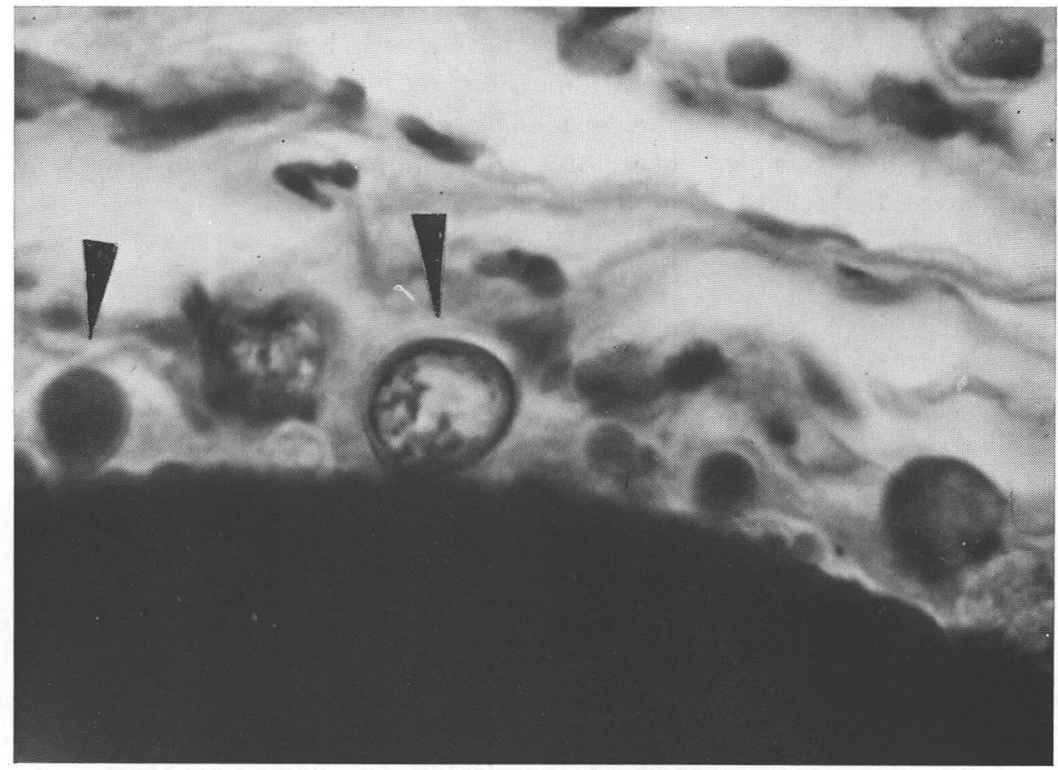

FIG. 10. - Detailed view on a spherical, double-contoured body with an already differentiated granular content. Other bodies (arrow) close-by. M. agrestis; McManus (× 1000$)$ 
in its close vicinity. Inspection of the lungs of animals with spontaneous infection disclosed spherical bodies in the vicinity of the mother adiaspore; their diameter was half of that of the large adiaspore, the shape was similar to that of the daughter spherule. The author concluded on the basis of these findings that reproduction of adiaspores may occur, under certain conditions, in the lungs of animals with spontaneous infection. Slais et al. $(1970 \mathrm{~b})$ reffered briefly to «special verrucose formations $\gg$ on the outer wall surface of E. crescens adiaspores from mice with experimental infection without adding a detailed description or drawing. Similarly, Fingerland (1971) described verrucose formations from the surface of adiaspores, but did not offer an explanation. Slais and Stěrba (1971) reported the finding of minute adiaspores, and of the so-called external bodies at various stages of constriction from the abdominal cavity of mice with experimental E. crescens infection. Also Hamáček at al. (1972) demonstrated the budding of adiaspores in granulomas originating in mice after intraperitoneal infection.

Our findings indicate that daughter adiaspore may originate also in the lungs of host with spontaneous adiaspiromycosis. Their location close or even in the bronchus suggests that they are either expectorated or, by contrast, inhaled deeper into the lungs. Hence, infection may be acquired from an endogenous source and this may explain lung changes of different age even without reinfection of the host.

The finding of minute adiaspores in A. flavicollis and A. sylvaticus from Bulgaria may indicate that infection was caused either by $E$. parva (we are in favour of this first assumption in view of the uniformity of the adiaspores and of several of their morphological features) or that infection with E. crescens was at its initial stage; the final possibility is that the animals were infected with both species. We are fully aware of the fact that it is almost impossible to differentiate the two Emmonsia species only on the basis of morphological signs although Sharapov (1969) considered these signs to be fully reliable. Therefore, our assumptions will have to be confirmed by cultivation of the fungus from the pathological material.

\section{References}

Bakerspigel (A.), 1968. - Canadian species of Sorex, Microtus and Peromyscus infected with Emmonsia. Mycopathologia et Mycologia applicata, 34, 273-279.

Doory (Y.), Al., Vice (T. E.) et Mainster (M. E.), 1971. - Adiaspiromycosis in a dog. J.A.V.M.A., 159, 87-90.

Dvořák (J.), 1966. - Doctor Dissertation Thesis, unpublished.

— et OčEnášEx (M.), 1965. - Adiaspiromycosis (Adiaspiromykóza). Čs. epidemiol. mikrobiol., imunobiol., 14, 65-68.

Fingerland (A.), 1971. - Histological similarities and differences of adiaspiromycosis, rhinosporidiosis and some other mycoses. (Histologické podobnosti a rozdíly adiaspiromykózy, rhinosporidiózy a někter`’ch dalších mykóz). Sborník přednášek XXII. ceolstát. sjezdu čs. patologư. 
H^Máček (F.), Semecký (V.), Dvořák (J.) et OtčenAšEK (M.), 1972. - Beitrag zur Morphologie der Adiasporen von Emmonsia crescens Emmons et Jellison, 1960. Mykosen, 15 (8), 315-326.

Sharapov (V. M.), 1969. - Adiaspiromycosis in USSR (Adiaspiromikoz v SSSR). Izvěstija sibirskogo otdělenija Akademii nauk SSSR, 1, 86-95.

SLAIS (J.), Dvořák (J.) et OTČENášEK (M.), $1970 a$. - The morphology of solitary adiaspores of Emmonsia crescens from the lung of man. Folia parasitologica (Praha), 17, 177-182.

—, HAMáčEK (F.), ŠTěRba (J.), $1970 \mathrm{~b}$. - Internal bodies of adiaspores of Emmonsia crescens in the lungs of mice. Folia parasitologica (Praha), 17, 319-322.

—, StěRbA (J.), 1971. - Morphology of experimental and spontaneous adiaspiromycosis. (Morfologie pokusné a spontánní adiaspiromykózy). Sborník přednášek, XXII. celostát. sjezdu čs. patologion. 